\title{
Polyphasic approach to a characteristic Ulva population from a limno-rheocrenic, mineral (chloride, sodium, sulphate) spring in the Siwa Oasis (Western Desert of Egypt)
}

\author{
Abdullah A. SABER ${ }^{1 *}$, Jan MAREŠ ${ }^{2,3}$, Graziano Guella ${ }^{4,5}$, Andrea ANESI ${ }^{4}$, Lenka \\ ŠTENCLOVÁ $^{2,3} \&$ Marco CANTONATI $^{6}$
}

\author{
${ }^{1}$ Botany Department, Faculty of Science, Ain Shams University, Abbassia Square-11566, Cairo, Egypt; \\ *Corresponding author e-mail: abdullah_elattar@sci.asu.edu.eg \\ ${ }^{2}$ The Czech Academy of Sciences, Biology Centre, Institute of Hydrobiology, Na Sádkách 7, CZ-37005 České \\ Budějovice, Czech Republic \\ ${ }^{3}$ Faculty of Science, University of South Bohemia, Department of Botany, Branišovská 1760, CZ-37005 České \\ Budějovice, Czech Republic; e-mail: jan.mares@centrum.cz \\ ${ }^{4}$ Department of Physics, Bioorganic Chemistry Lab, University of Trento, Via Sommarive 14, 38123 Povo, \\ Trento, Italy \\ ${ }^{5}$ CNR, Institute of Biophysics, Trento, Via alla Cascata 56/C, 38123 Povo, Trento, Italy; e-mail: graziano. \\ guella@unitn.it; andrea.anesi@unitn.it \\ ${ }^{6}$ MUSE - Museo delle Scienze, Limnology \& Phycology Section, Corso del Lavoro e della Scienza 3, I-38123 \\ Trento, Italy;e-mail: marco.cantonati@muse.it
}

\begin{abstract}
An interesting population of ulvacean green algae was collected from a limno-rheocrenic, thermal, mineral (chloride, sodium, sulphate) spring known as "Ain Abu Sherouf" in the Siwa Oasis, the Western Desert of Egypt. A detailed combined investigation on its morphotaxonomy, autecology, and a multilocus sequence data set including the chloroplast-encoded $r b c \mathrm{~L}$ gene and the nuclear-encoded nrDNA SSU and ITS allowed us to identify this population as Ulva flexuosa subsp. paradoxa (syn. Ulva paradoxa, Ulvales, Chlorophyta), although the algal thalli were in average narrower than usual in this taxon. Analysis of the molecular $r b c$ L-ITS sequencing data demonstrated a close phylogenetic relationship of the studied population to two Ulva isolates from Japan and China and their taxonomic status was further discussed. The pigment profiling confirmed chlorophylls and carotenoids typical of the Ulvaceae (lutein, $\alpha / \beta$-carotenes, violaxanthin, and neoxanthin). Lipidomic analysis revealed the presence of the monogalactosyl diacylglycerols (MGDG), digalactosyl diacylglycerols (DGDG), sulfoquinovosyl diacylglycerols (SQDG), and diacylglyceryl $N, N, N$-trimethylhomoserine (DGTS) lipid classes. Presence of the plasma membrane DGTS lipids in remarkable proportion might be an adaptation to this nutrient-poor mineral spring habitat, with relatively low phosphorus values. The lower unsaturation index (UI) values of the plastidial DGDG and SQDG lipids are likely to reflect the need to maintain adequate membrane fluidity in this thermal mineral spring system. This polyphasic study not only extended our little knowledge on the distribution, autecology, and adaptive mechanisms of $U$. flexuosa subsp. paradoxa in the Saharan habitats of Africa, but also re-assessed and refined the taxonomic and phylogenetic affiliation of previously sampled close relatives from East Asia.
\end{abstract}

Key words: Ulva flexuosa subsp. paradoxa, Chlorophyta, Saharan habitats, mineral spring, morphotaxonomy, molecular phylogeny, adaptive mechanisms, Siwa Oasis, Egypt

\section{INTRODUCTION}

The genus Ulva Linnaeus (Chlorophyta: Ulvales), including previously described taxa of the genus Enteromorpha Link (HAYDEn et al. 2003; SHimada et al. 2003), is known to be widely distributed in a variety of aquatic biotopes, i.e. marine coasts (e.g., YoshidA et al. 2015;
PHILLIPS et al. 2016 and references therein), estuaries (Shimada et al. 2008; Hofmann et al. 2010), brackish lakes (MaLTA et al. 2002; OGAWA et al. 2013), and also in rivers, channels, pools, and springs (e.g., ICHIHARA et al. 2009; JoHn et al. 2011; RYBAK 2015, 2016). The accurate delimitation of Ulva species is highly problematic due to their relatively simple morphotaxonomic structures 
with notoriously overlapping characteristics (DUAN et al. 2012; Melton et al. 2016). In addition, intraspecific, phenotypic-plasticity phenomena in response to different environmental factors have also been described (e.g., Blomster et al. 1999; Messyasz \& RybaK 2011; KeEsING et al. 2016; RYBAK 2018). Nevertheless, progress in refined species discrimination has been achieved during the last decades utilizing molecular phylogeny based on several well-sampled genomic markers, such as the nrDNA internal transcribed spacer (ITS) regions, $5 \mathrm{~S}$ rDNA, the large subunit of RuBisCO $(r b c \mathrm{~L})$, and the chloroplast protein synthesis elongation factor Tu (tufA) genes (e.g., KRAFT et al. 2010; MAREŠ et al. 2011; KAZI et al. 2016; HirAoKA et al. 2017).

The species complex of Ulva flexuosa Wulfen [syn. Enteromorpha flexuosa (Wulfen) J. Agardh] usually grows in form of abundant tubular monostromatic thalli, and can be considered an opportunistic, invasive, and fouling green macroalgal species (LOUGHEED \& SteVenson 2004; LiU et al. 2013; LeE et al. 2014). A classical and authentic monography on the order Ulvales by BLIDING (1963) identified five subspecies [including the subspecies paradoxa (C. Agardh) M.J. Wynne] and one variety as belonging to this species complex. Nevertheless, these taxa still form a taxonomic puzzle (RYBAK et al. 2014) and they are in need for in-depth combined studies, especially in Africa that is barely touched in this respect. Recent contribution of KRAFT et al. (2010) on the true species diversity of the genus Ulva in Australian waters identified some interesting $U$. flexuosa specimens only based on the anatomical structure but they also strongly suggested that this material might represent a novel or cryptic taxon because of its inconsistency with GenBank molecular data. In general, molecular studies of MAREš et al. (2011) and RYBAK \& CzERWONIEC (2015) highlighted the monophyletic origin of three subspecies of the $U$. flexuosa complex [subsp. flexuosa, paradoxa, and pilifera (Kützing) M.J. Wynne].

From the ecological standpoint, the Ulva flexuosa subspecies complex in general appears to have wide distributional niches in all continents from freshwater to hyperhaline, and sometimes brine habitats, i.e. in different European inland waters (e.g., MEssYasz \& RYBAK 2009; RYBAK \& GĄBKA 2017), in North America (LOUGHEED \& Stevenson 2004; Fleming 2016), and also in some Asian countries (e.g., Shimada et al. 2008; LeE et al. 2014; HiraOKA et al. 2017 and references therein). Remarkably, the subsp. paradoxa can inhabit both marine and inland waters. In inland waters it is considered an indicator of mineral spring water habitats (BLIDING 1963; MAREŠ et al. 2011), occasionally present also in heavily anthropogenically impacted ecosystems rich in nutrient and salt content, and can tolerate salinity values exceeding 50 PSU (RYBAK et al. 2014; RYBAK 2015, 2018). This represents a difference with respect to the similar subspecies pilifera, which seems to be restricted to freshwater habitats, such as ponds and small streams, and occurs under lower nutrient and salt concentrations
(MAREŠ et al. 2011; RYBAK \& CZERWONIEC 2015). To our knowledge, there have been no previous studies discussing the ecophysiological adaptive mechanisms (regarding pigments and membrane lipid contents) of the subsp. paradoxa and how these may relate to mineralization, and thermal and irradiance niches.

Previous research on the order Ulvales in Egypt surveyed many Ulva spp. mainly from the Mediterranean and Red Sea coasts (e.g., AleEM 1993; FAKHrY et al. 2007 and many references therein), the Suez Canal (El-Shoubaky \& Hamed 2006; El Shoubaky 2015), and brackish estuaries of the Nile River (SHAABAN et al. 2012). With the exception of the taxa found in these coastal and brackish habitats, the species complex of U. flexuosa was rarely noticed (EL SHOUBAKY 2005, 2013). Moreover, AвоU EL-KHEIR \& MeKkey (1986) and SHANAB (2006) recorded E. flexuosa (currently accepted taxonomically as $U$. flexuosa) and E. compressa (Linnaeus) Nees (U. compressa Linnaeus according to current nomenclature) in the thermal inland mineral spring 'Ain Helwan' located near Cairo. SHAABAN (1985) also found E. torta (Mertens) Reinbold [currently U. torta (Mertens) Trevisan] in the Siwa Lake, Western Desert of Egypt. All the above mentioned investigations were only based on morphotaxonomic characteristics. A recent contribution of ISMAIL and MoHAMED (2017) discussed the phylogenetic relationships of four different Ulva species (U. compressa, U. fasciata, U. lactuca, and $U$. linza) using the random amplified polymorphic DNA (RAPD) technique. However, they emphasized the necessity of re-investigation of the members of the order Ulvales using suitable and well-sampled gene markers. Springs are multiple ecotones linking ground- and surface water, springhead and spring-stream, and submerged to terrestrial biotopes (REISS \& CHIFFLARD 2017). The most typical and well known feature of permanent springs fed by large and deep aquifers is the high environmental stability (i.e. very limited fluctuations of physical and chemical characteristics) (CANTONATI et al. 2006, 2012). Spring habitats are also valuable hotspots for biodiversity conservation (e.g., NowICKA-KRAWCZYK \& ŻELAZNAWieCZOREK 2016; LeHOSMAA et al. 2017), and refugia for rare and threatened biota (e.g., BRAVAKos et al. 2016; SABER et al. 2017). However, they are highly menaced by diverse human impacts, the most important being over-exploitation of the water they discharge (PowELL et al. 2015; Powell \& Fensham 2016).

The primary goal of this work was to in-depth investigate an interesting population of Ulva flexuosa subsp. paradoxa found in an inland, limno-rheocrenic, thermal, mineral spring known as "Ain Abu Sherouf" in the Saharan habitat of the Siwa Oasis (Western Desert of Egypt) using a combination of techniques (genetics, morphotaxonomy, membrane-lipid and pigment analyses, and ecology), and relating these to potential adaptive mechanisms of this taxon to its thermal and mineral, groundwater-dependent habitat. A taxonomic discussion of previously-sampled close relatives, based 
on information available in the GenBank database, was another goal.

\section{Material ANd Methods}

Study site. Specimens of Ulva flexuosa subsp. paradoxa investigated in the present study were collected on July $24^{\text {th }} 2016$ from the calcareous outlet channel of an inland, thermal, mineral spring known as "Ain Abu Sherouf" $\left(29^{\circ} 10^{\prime} 57^{\prime \prime N}, 25^{\circ} 44^{\prime} 30.4^{\prime \prime E}\right)$ in the Siwa Oasis (Western Desert, Egypt) at an elevation of -9.0 $\pm 7.3 \mathrm{~m}$ b.s.l. (Fig. 1a). Its water, with flow velocity $<0.5 \mathrm{~m} . \mathrm{s}^{-1}$, is mainly used for agricultural purposes in this harsh Saharan habitat. Fish farming in its main springhead was also noted. This spring, characterized by a relatively stable water temperature of ca. $26^{\circ} \mathrm{C}$, is categorized as "thermal" based on the classification system reported by GLAZIER (2009), who identified thermal springs as those with water temperatures clearly above the mean annual air temperature (which is ca. $22{ }^{\circ} \mathrm{C}$ in the Siwa Oasis). The main springhead is surrounded by concrete walls and fully exposed to sunlight (Figs 1b,c). The Siwa Oasis (ca. $800 \mathrm{~km}^{2}$ ) is one of the smallest depressions occupying the northwestern part of the Western Desert, and topographically lies at about 10-17 m below the sea level (EL-SABBAGH et al. 2017). It is located at ca. $600 \mathrm{~km}$ west of Cairo between latitudes $29^{\circ} 02^{\prime}$ and $29^{\circ} 28^{\prime \prime} \mathrm{N}$ and longitudes $25^{\circ} 12^{\prime}$ and $26^{\circ} 02^{\prime} \mathrm{E}$; approximately $300 \mathrm{~km}$ south of the Egyptian Mediterranean Sea coast, and near the Libyan-Egyptian border (EL-SABbaGH \& El Hedeny 2016). The Siwa Oasis is noticeably characterized by a hot hyper-arid desert climate with an average annual precipitation of less than $10 \mathrm{~mm}$ per year (Powell \& Fensham 2016). Groundwater is the only available water resource in this vast Saharan ecosystem. The uppermost zone feeding the Siwa Oasis is primarily typified by its artesian brackish-to-saline water type derived from the Fissured Complex Carbonate Aquifer occupying the Western Desert and having a thickness of ca. $650 \mathrm{~m}$ (Upper Cretaceous to Middle Miocene zones) with a water mineral content ranging between 1,500 to $7,000 \mathrm{mg} .1^{-1}$ (ABDULAZIZ \& FAID 2015). The deeper drilled wells, providing typical freshwater in the oasis, are mainly supplied by the worldwide largest non-renewable water resource, the Nubian Sandstone Aquifer System (Voss \& Soliman 2014).

Hydrochemical characterization. Water sampling was conducted using clean polyethylene bottles. Water temperature $\left({ }^{\circ} \mathrm{C}\right), \mathrm{pH}$, specific conductivity $\left(\mu \mathrm{S} . \mathrm{cm}^{-1}\right)$, and total dissolved solids $\left(\mathrm{mg} . \mathrm{l}^{-1}\right)$ were measured in situ using the calibrated portable Temp/pH/ EC/T.D.S. meter HANNA HI 991301. Dissolved Oxygen (D.O.) was also determined using the in-field-calibrated dissolved oxygen meter Lutron ${ }^{\circledR}$ YK-22DO. Detailed hydrochemical characteristics of Ain Abu Sherouf, including major ions, nutrients, trace elements and metals, were determined following standard procedures and methods adopted by Chapman \& PratT (1978) and ClesCERI et al. (2000). Metals and trace elements were analyzed by means of ICP-OES (Optima 5300 Perkin Elmer Corp.). The ions, $\mathrm{Na}^{+}$, $\mathrm{Ca}^{2+}, \mathrm{Mg}^{2+}, \mathrm{Cl}^{-}, \mathrm{HCO}_{3}^{-}$and $\mathrm{SO}_{4}^{2-}$, were measured using ionic chromatography (ICS 1500 Dionex Corp.). The nutrients $\left(\mathrm{NO}_{3}^{-}\right.$, $\mathrm{NO}_{2}^{-}, \mathrm{NH}_{4}^{+}$, TP and SRP) were assessed by molecular absorption spectrometry, and silica $\left(\mathrm{SiO}_{2}\right)$ by the molybdosilicate method. Sampled algal materials. Specimens included in this study were collected by hand and forceps in $100 \mathrm{ml}$ sterile clean polyethylene terephthalate (PET) bottles and transported chilled in the ice-box to the laboratory for further studies. The algal materials were collected from the calcareous rocky outlet channel of Abu Sherouf spring and as epiphytes growing on the common reed Phragmites australis proliferating in this outlet channel (Fig. 1d). In the lab, the specimens were cleaned well using distilled water to remove epiphytes and debris. This step was verified by microscopic examination. Subsequently, the specimens were divided into four portions. The first portion was dried in silica desiccant for DNA extraction, the second portion was fixed in $4 \%(\mathrm{v} / \mathrm{v})$ formaldehyde solution for the morphotaxonomic identification, the third portion that was well-cleaned was immediately used for lipidomics and bioorganic screening, and the fourth portion was stored as a voucher specimen in the Phycology Unit NO. 341 at the Botany Department, Faculty of Science, Ain Shams University, Cairo, Egypt, and the MUSE-Museo delle Scienze, Trento, Italy. For morphological identification and to visualize chloroplast autofluorescence, specimens were examined using both Zeiss Axioskop 2 microscope (Zeiss, Jena, Germany) in Italy and BEL $^{\circledR}$ photonics biological microscope (BEL ${ }^{\circledR}$ Engineering Co., Monza, Italy) in Egypt. Morphometric diagnostic features were measured and photographed using Axiocam and Canon Powershot G12 digital cameras. A total of 50 measurements/observations were made in ca. 20 well-grown individuals for the taxonomically important features: (1) general morphology, length, and width of the thallus, (2) the structure of the basal region of the main axis and branches (number and position), (3) the structure of the tip of branchlets, (4) form, size and arrangement of the cells in surface view, (5) the appearance of chloroplast in surface view, (6) the shape and number of pyrenoids per cell which are considered as a main anatomical feature with a high taxonomic value. Neither asexual zoospores nor gametes were noticed in any of the studied samples. Specimens were morphologically identified using the relevant literature of BLIDING (1963) and following the modern nomenclature adopted by WYNNE (2017).

Molecular and phylogenetic analyses. The total genomic DNA was extracted from a silica-dried specimen after pulverization in a Mixer Mill MM200 (Retsch, Haan, Germany) laboratory mill with wolfram carbide beads ( $\left.3 \mathrm{~min}, 30 \mathrm{~s}^{-1}\right)$ using a modified xanthogenate-sodium dodecyl sulfate buffer extraction protocol with addition of 3\% polyvinyl polypyrrolidone and polyethylene glycol- $\mathrm{MgCl}_{2}$ precipitation (YILMAZ et al. 2009). Three parts of the genome were subjected to PCR amplification: 1) internal transcribed spacer (ITS) 1-5.8S-ITS2 part of the ribosomal cistron, the small subunit (SSU) rRNA gene, and the chloroplast ribulose-1,5,-bisphosphate carboxylase $(r b c \mathrm{~L})$ gene. Total genomic DNA (5-20 ng) was added to PCR reactions, each containing $12.5 \mu \mathrm{l}$ of the Plain PPMaster Mix ( $2 \times$ concentration; Top-Bio, Prague, Czech Republic), 6.25 pmol of each primer, and sufficient PCR Water (Top-Bio) to obtain a final volume of $25 \mu \mathrm{l}$. The PCR and sequencing primers and protocols and the amplification procedures were exactly identical to those used by MAREŠ et al. (2014). The PCR products were purified with the JETQUICK PCR Purification Spin Kit (Genomed, GmbH, Löhne, Germany) or Invisorb Fragment CleanUp kit (Stratec Molecular $\mathrm{GmbH}$, Berlin, Germany) according to manufacturer's instructions and sequenced directly in a commercial sequencing laboratory (SeqMe, Dobříš, Czech Republic). The sequences were deposited in GenBank under accession numbers MG923834, MG923960, and MG934373 for ITS, 18S rDNA, and $r b c$ Lenes, respectively.

We analyzed electropherograms and assembled final nucleotide sequences with the SeqMan 5.06 (BurLand 1999) computer application. BLAST hits close to our original sequences and representatives of other species of Ulva and selected genera of Ulvophyceae from the NCBI nucleotide collection were added to the alignments, which were subsequently used for phylogenetic reconstructions. The outgroup taxa and additional isolates with both ITS and $r b c \mathrm{~L}$ sequences available for combined analysis were added based on previously published studies that used these two phylogenetic markers (HAYDEN \& WAALAND 2002; HAYDEN et al. 2003; O'Kelly et al. 2004; ICHIHARA et al. 2009; Kraft et al. 2010; LIU et al. 2010; MAREŠ et al. 2011; DuAN et al. 2012; Ogawa et al. 2013; Mareš et al. 2014; RYBAK \& CZERwonieC 2015). The SSU rRNA data set was analysed separately because the set of isolates with available sequence (from NCBI) did not overlap with the set of isolates having the other two markers 
sequenced. The nucleotide alignments were obtained using MAFFT (version 7; KATOH \& STANDLEY 2013) running the G-INS-i (SSU rRNA), E-INS-i ( $r b c \mathrm{~L})$, or Q-INS-I (ITS) algorithms (with default parameters). The resulting alignments were corrected manually in BioEdit (version 7.0.9.0; HaLl 1999). Ambiguously aligned gappy regions in the ITS alignment were removed automatically using Gblocks (TALAVERA \& CASTRESANA 2007) prior to manual editing. Pairwise sequence distances were calculated as $\mathrm{p}$-distance using the Sequence Identity Matrix command in BioEdit using alignments cut down to the sequence length of our isolate from Egypt; short sequences (RYBAK \& CZERWONIEC 2015) were exluded from the analysis.

The best-fitting nucleotide substitution models for ML-based phylogenetic methods were estimated using Akaike Information Criterion (AIC) values (jModel Test 2.1.6.; GuINDON \& GASCUEL 2003; Darriba et al. 2012) for each of the loci separately. Submodels from the generalized time-reversible model (GTR) family with the estimated proportion of invariable sites (I) and gamma-distributed rate variation (G) were selected by the software for each data set (SSU rRNA: Tim $2+\mathrm{I}+\mathrm{G} ; r b c \mathrm{~L}$ : Tim3 $+\mathrm{I}+\mathrm{G}$; ITS Tim2 $+\mathrm{I}+\mathrm{G})$. Because the programs selected for Maximum Likelihood (ML) phylogenetic analysis (RaxML v.8; StAMATAKIs 2014) and Bayesian Inference (BI) calculation
(MrBayes 3.2.6; RoNQUisT et al. 2012) currently provide only few options for calculation with GTR models, the closest (but more general) GTR $+\mathrm{I}+\mathrm{G}$ substitution model was employed in all subsequent analyses. For the $r b c \mathrm{~L}$ and ITS datasets intended for further combined analysis, an initial ML analysis with 1000 bootstrap pseudo-replications was run with each of the loci separately. The resulting phylogenies were confronted manually to reveal and eliminate taxa exhibiting incongruent positions in the individual gene trees (no such taxa were detected). The two concordant matrices were then concatenated prior to the final analysis. The alignment line of Ulva flexuosa BY02, a close relative of the material under study, consisted only from ITS data - the $r b c \mathrm{~L}$ sequence for this isolate is not available and was treated as missing data. All gaps and missing regions at the 5 'and $3^{\prime}$ ends of sequences included in all the alignments were also treated as missing data. The final phylograms (the SSU rRNA tree and the tree inferred from a concatenated $r b c \mathrm{~L}+\mathrm{ITS}$ alignment) presented in this study were reconstructed using BI. The BI calculation involved two runs of eight Markov Chains Monte Carlo (MCMC) for 1-2 million generations, sampled each 100 generations until the convergence criterion reached a value $<0.01$. The first $25 \%$ of the sampled data was discarded as burn-in. ML analysis was performed as previously with 1000

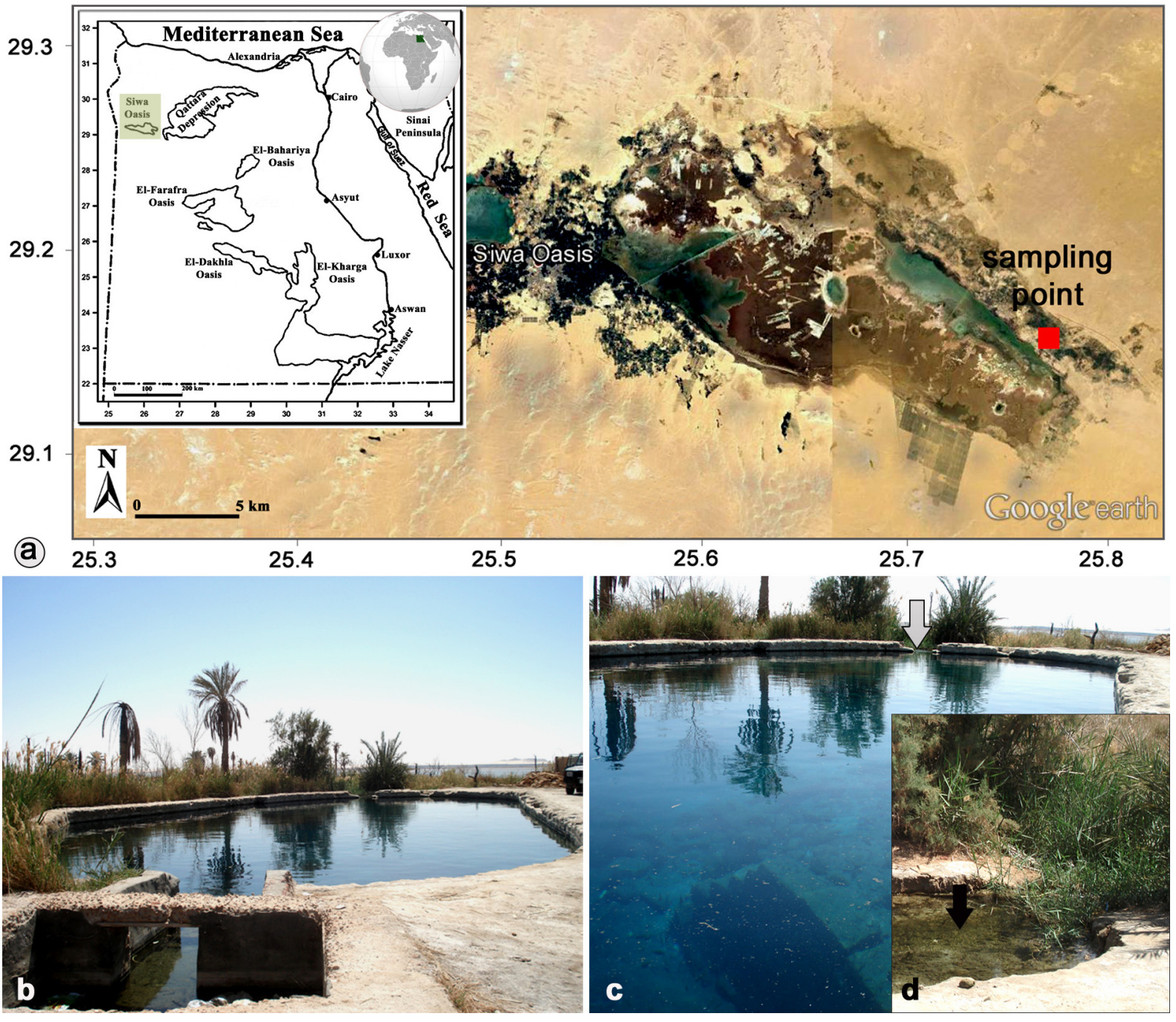

Fig. 1. Ulva flexuosa subsp. paradoxa sampling site: (a) Google earth satellite image showing location of the sampling site in the Siwa Oasis, the Western Desert of Egypt; (b-c) landscape views of the springhead of Ain Abu Sherouf in the Siwa Oasis (arrow indicates to its outlet channel); (d) mass growth of the green thallus $U$. flexuosa subsp. paradoxa growing on the calcareous outlet channel of Ain Abu Sherouf spring (arrowhead), and also as epiphytic on the common reed Phragmites australis. 
Table 1. Physical and chemical characteristics of the inland thermal mineral spring "Ain Abu Sherouf” inhabited by the Siwa Ulva flexuosa subsp. paradoxa population.

\begin{tabular}{|c|c|}
\hline Parameter & Ain Abu Sherouf \\
\hline Temperature $\left({ }^{\circ} \mathrm{C}\right)$ & 26.3 \\
\hline $\mathrm{pH}$ & 6.46 \\
\hline Conductivity $\left(\mathrm{mS} . \mathrm{cm}^{-1}\right)$ & 10.54 \\
\hline T.D.S. $\left(\mathrm{mg} . \mathrm{l}^{-1}\right)$ & 5300 \\
\hline Dissolved oxygen $\left(\mathrm{mg} .1^{-1}\right)$ & 4.1 \\
\hline $\mathrm{Na}^{+}\left(\mathrm{mg} .1^{-1}\right)$ & 1946.57 \\
\hline $\mathrm{K}^{+}\left(\mathrm{mg} \cdot \mathrm{l}^{-1}\right)$ & 83.22 \\
\hline $\mathrm{Ca}^{2+}\left(\mathrm{mg} .1^{-1}\right)$ & 387.21 \\
\hline $\mathrm{Mg}^{2+}\left(\mathrm{mg} \cdot \mathrm{l}^{-1}\right)$ & 268.11 \\
\hline $\mathrm{Cl}^{-}\left(\mathrm{mg} \cdot \mathrm{l}^{-1}\right)$ & 3526 \\
\hline $\mathrm{HCO}_{3}^{-}\left(\mathrm{mg} \cdot 1^{-1}\right)$ & 220.37 \\
\hline $\mathrm{CO}_{3}^{2-}\left(\mathrm{mg} \cdot 1^{-1}\right)$ & 0.0 \\
\hline $\mathrm{SO}_{4}^{2-}\left(\mathrm{mg} .1^{-1}\right)$ & 1207.65 \\
\hline $\mathrm{NO}_{3}^{-}\left(\mu \mathrm{g} . l^{-1}\right)$ & 580 \\
\hline $\mathrm{NO}_{2}^{-}\left(\mu \mathrm{g} .1^{-1}\right)$ & 5 \\
\hline $\mathrm{NH}_{4}^{+}\left(\mu \mathrm{g} .1^{-1}\right)$ & 2.5 \\
\hline $\mathrm{TP}\left(\mu \mathrm{g} .1^{-1}\right)$ & 28 \\
\hline S.R.P. $\left(\mu g .1^{-1}\right)$ & 3 \\
\hline $\mathrm{SiO}_{2}\left(\mathrm{mg} .1^{-1}\right)$ & 5.9 \\
\hline $\operatorname{Sr}\left(\mu \mathrm{g} .1^{-1}\right)$ & 5185 \\
\hline $\operatorname{Li}\left(\mu \mathrm{g} .1^{-1}\right)$ & 61.5 \\
\hline $\mathrm{Rb}\left(\mu \mathrm{g} . \mathrm{l}^{-1}\right)$ & 42.0 \\
\hline $\mathrm{Fe}\left(\mu \mathrm{g} .1^{-1}\right)$ & 20.6 \\
\hline $\mathrm{Ba}\left(\mu \mathrm{g} .1^{-1}\right)$ & 15.9 \\
\hline $\mathrm{V}\left(\mu \mathrm{g} .1^{-1}\right)$ & 9.4 \\
\hline $\operatorname{Cr}\left(\mu \mathrm{g} .1^{-1}\right)$ & 4.0 \\
\hline $\mathrm{U}\left(\mu \mathrm{g} .1^{-1}\right)$ & 3.6 \\
\hline $\mathrm{Ni}\left(\mu \mathrm{g} .1^{-1}\right)$ & 1.92 \\
\hline $\mathrm{Zn}\left(\mu \mathrm{g} .1^{-1}\right)$ & 0.91 \\
\hline $\operatorname{Mn}\left(\mu \mathrm{g} .1^{-1}\right)$ & 0.85 \\
\hline $\mathrm{Cu}\left(\mu \mathrm{g} \cdot 1^{-1}\right)$ & 0.48 \\
\hline
\end{tabular}

bootstrap pseudo-replications, and the resulting bootstrap values were mapped onto the $\mathrm{BI}$ tree. Both $\mathrm{ML}$ and $\mathrm{BI}$ analyses were run using the CIPRES supercomputing facility (MILLER et al. 2012). Phylogenetic trees were drawn and edited using FigTree (version 1.4.2; http://tree.bio.ed.ac.uk/software /figtree/).

Lipid and pigment analyses. Total lipids were extracted by a slightly modified Folch method (FoLCH et al. 1957). Briefly, cell clusters were collected into $15 \mathrm{ml}$ glass tubes, re-suspended in
$10 \mathrm{ml}$ of chloroform/methanol 2:1 (v/v), sonicated for $15 \mathrm{~min}$ in an ultrasonic bath (Sonorex Super, Bandelin electronics, Berlin, Germany), and centrifuged at $3000 \times \mathrm{g}$ for $10 \mathrm{~min}$ at room temperature to separate the organic phase (bottom layer). For each cell pellet, the extraction procedure was repeated three times. All the organic phases were collected, filtered by using glass filters under vacuum, and reduced to dryness on a rotary evaporation (Büchi Labortechnik AG, Flawil, Switzerland) to obtain crude lipid extracts. Extracts were re-suspended in $300 \mu \mathrm{l}$ of methanol/ chloroform 9:1 (v/v).

Crude lipid extracts were subjected to Reverse Phase Liquid Chromatography-Electrospray Ionization-Ion Trap-Mass Spectrometry analyses (RPLC-ESI-IT-MS). Under this chromatographic setup, lipid molecular species were separated primarily according to the hydrophobicity of their acyl chains. Details are reported in Guella et al. (2003). Hydrophilic Interaction LIquid Chromatography (HILIC) was also used to establish the membrane lipid class composition based on the different polarity of lipids head groups (ANESI \& GUELLA 2015).

Each lipid molecular species was quantified with respect to the total area of all lipid species belonging to the same class (e.g., relative quantification of $\mathrm{MGDG}_{\mathrm{x}}$ was performed with respect to total area of MGDG). The unsaturation index (UI) and the average chain length (ACL) were calculated for each lipid class, using the formulas UI ${ }_{\text {class } y}=\Sigma$ (relative area lipid $*$ double bond number of lipid $)_{x}$ and ACL $L_{\text {class } y}=\Sigma\left(\right.$ relative area lipid ${ }_{x}^{*}$ acyl chain length of lipid ${ }_{x}$ ) where lipid represents each single molecular species belonging to the $y$ lipid class, respectively. The ratio between MGDG and DGDG was calculated as $[\Sigma$ area MGDG/ $\Sigma$ area $\mathrm{DGDG}]^{*} \mathrm{~F}$; where $\mathrm{F}$ is the normalization ratio obtained by using internal standard (FLAIM et al. 2014). In particular, the ESI-MS relative response factors (F) for the 2 lipid classes was established with MGDG (18:3/16:3) and DGDG (18:3/18:3) standards. Pigments (chlorophylls and carotenoids) were simultaneously analyzed in the same chromatographic conditions through a Photo-Diode-Array detector (PDA) operating at 470 $\mathrm{nm}$ (carotenoids) and $660 \mathrm{~nm}$ (chlorophylls). Chromatographic peaks were identified by comparing retention times and online spectra (UV-Vis and positive and negative-ion ESI-MS spectra) against known standards (Frassanito et al. 2005).

\section{ResUlts}

\section{Ecological features}

Physical and chemical data of the inland, thermal, mineral (chloride, sodium, sulphate) spring Ain Abu Sherouf including the primary ions, nutrients, trace elements and metals' concentrations are listed in Table 1. Despite the very high conductivity $\left(10.54 \mathrm{mS} . \mathrm{cm}^{-1}\right)$, the water was only very-slightly acidic ( $\mathrm{pH}$ 6.46). $\mathrm{NaCl}$ constituted the major dissolved salt with noteworthy amounts of sulphate and $\mathrm{Mg} / \mathrm{Ca}-$ bicarbonate. Nitrate and SRP concentrations were very low, confirming the oligo-mesotrophic condition suggested by a total phosphorus value of $28 \mu \mathrm{g} . \mathrm{l}^{-1}$. Trace elements and heavy metals having notable concentrations were $\mathrm{Sr}, \mathrm{Li}, \mathrm{Rb}$, $\mathrm{Fe}$, and $\mathrm{Ba}$, reflecting some hydrochemical features of the Fissured Complex Carbonate Aquifer in this desert area and some bedrock characteristics of the Siwa Oasis (check Table 1 for more details).

Morphological characterization (Figs 2a-i; Figs S1a-h) Thallus of the studied green macroalgae is relatively 
small, light green, tubular, filiform, 1-4 cm long, 100-250 $\mu \mathrm{m}$ wide, intensively ramified (Figs $2 \mathrm{a}-\mathrm{c}$ ). Branches of variable size are frequent throughout the thallus. Cells are commonly rectangular to quadrangular, $11-22(-24) \mu \mathrm{m}$ long $(16.5 \pm 3.5 ; \mathrm{n}=50), 9-16(-18) \mu \mathrm{m}$ wide $(13 \pm 2.2$; $\mathrm{n}=50)$, mostly arranged in long rows. In central areas of the thalli, the cells sometimes get rather polygonal to rounded-polygonal in shape and are irregularly positioned (Figs 2d-g). Branchlets occur abundantly and are terminated by small rounded-conical cells (Fig. 2i), approximately $12-15 \mu \mathrm{m}$ long, $9-10 \mu \mathrm{m}$ wide. Chloroplasts parietal, usually cover the majority of the cell walls (Fig. $2 \mathrm{~h}$ ), with 1-3 spherical pyrenoids, 2.5-3.5(-4) $\mu \mathrm{m}$ in diameter $(3.1 \pm 0.5 ; \mathrm{n}=50)$.

Both the qualitative and quantitative characteristics of the Siwa $U$. flexuosa population were assessed. The diagnostic characteristics in the key literature and in this study showed the specimens to be U. flexuosa subsp. paradoxa (check Table S1 for more details). Interestingly, the thallus width in the population studied (100-250 $\mu \mathrm{m}$ wide) was consistently close to the lower limit of the usual range in European samples, which can reach up to several $\mathrm{mm}$ in width (Table S1). Given that the thallus width may vary considerably and all other characteristics were within the ranges provided, the Siwa U. flexuosa population was assigned to the subsp. paradoxa on the basis of morphology.

\section{Sequencing data analysis}

Analysis of the SSU rRNA gene resulted in a phylogenetic tree (Fig. 3), which contained a highly supported monophyletic clade representing the genus Ulva (1.00/94 support values from BI/ML). Other genera of Ulvales such as Percursaria, Umbraulva, and Ulvaria were resolved as the closest relatives of this cluster. The Ulva flexuosa isolate under study was found in the middle of the Ulva clade, however having no close relatives among published SSU nrDNA sequences. The one and only available sequence designated as U. flexuosa (accession number AB425963) originating from Japan was settled in a different subclade in the tree. Therefore, our sequence can serve as reference SSU rRNA gene sequence (currently the only one available) for the true $U$. flexuosa complex in future studies.

The phylogenetic tree derived from the combined $r b c \mathrm{~L}$ and ITS data sets (Fig. 4) provided a better resolution within the closely allied Ulva flexuosa sequences. Majority of $U$. flexuosa, including the Egyptian isolate, formed a supported monophyletic clade $(0.99 / 72)$, which represented one of the major internal Ulva lineages. The clade was divided into three main supported subclades that are suggested to be identified with three subspecies of $U$. flexuosa: subsp. flexuosa, subsp. pilifera, and subsp. paradoxa established already in previous studies (MAREŠ et al. 2011; RYBAK \& CzERWONIEC 2015). The paradoxa subclade contained also two isolates from Japan and China designated as U. flexuosa subsp. linziformis and U. flexuosa, respectively, by their authors. These two sequences formed a very compact group together with the Egyptian sample, suggesting a close phylogenetic and taxonomic relationship.

The three subspecies clades were equivalent in the tree in terms of the level of branching and roughly also the branch lengths. Further analysis of pairwise ITS2 region sequence distances (Table 2) indicated a comparable range of divergence when comparing the three subspecies clades against each other (3.9-6.4\% $\mathrm{p}$-distance), while their internal divergence was consistently lower $(0.0-1.1 \% \mathrm{p}$-distance in ITS2). The highest internal sequence variability was observed within the paradoxa clade, in which the isolate from Egypt formed a sub-group together with the two isolates from Japan and China, as noted earlier (Fig. 4). The group of these three isolates exhibited a slightly higher distance up to $1.1 \%$ from some other paradoxa sequences (compared to $0.6 \%$ at maximum if these three isolates were excluded from the analysis). In the $r b c \mathrm{~L}$ data, the difference between the intra-subspecies and inter-subspecies sequence distances followed the same trend although it was less pronounced, as the overall similarity within the entire $U$. flexuosa clade was higher.

\section{Pigments and lipids}

The most abundant carotenoids in Ulva flexuosa subsp. paradoxa from the Siwa Oasis, as determined by LC-PDA analysis at $470 \mathrm{~nm}$, are lutein $(48.6 \%$ of total carotenoids), $\alpha / \beta$-carotene (18.8\%), violaxanthin (7.7\%) and neoxanthin (2.6\%) (Fig. 5a). Importantly, this species does not produce siphonaxanthin that represents the chemotaxonomic marker of Umbraulva, the genus most closely related to Ulva (BAE \& LEE 2001). Chlorophylls are dominated by chlorophyll- $a$ (relative area $71.1 \%$ ), chlorophyll- $b(5.8 \%)$, phaeophytin- $a(3.5 \%)$, and chlorophyll- $a$ isomer (3.5\%) (Fig. 5b).

Lipid composition was assessed by combining the information obtained from two complementary chromatographic conditions. HILIC chromatography allows us to determine the classes by separating lipid species according to their head-groups (inter-classes lipid separation) whilst in reverse phase chromatography the lipid species are separated according to the length of acyl chains and their degree of unsaturation (intraclasses separation).

This combined approach resulted in the identification of four major lipid classes (Table 3; Fig. 5c): the thylakoid lipids monogalactosyl-diacylglycerols (MGDG; 8 molecular species), digalactosyl-diacylglycerols (DGDG; 17 species) and sulfoquinovosyl-diacylglicerols (SQDG; 12 species), and the constituents of other cellular membranes such as the betaine lipids belonging to the DGTS class (diacylglyceryl- $N, N$, $N$-trimethylhomoserine; 62 molecular species). The ESI fragmentation pattern of DGTS is similar to their analogues diacylglyceryl-hydroxymethyl- $\beta$-alanine (DGTA) but interclass separation of DGTS from DGTA can be easily obtained in HILIC conditions due to the 

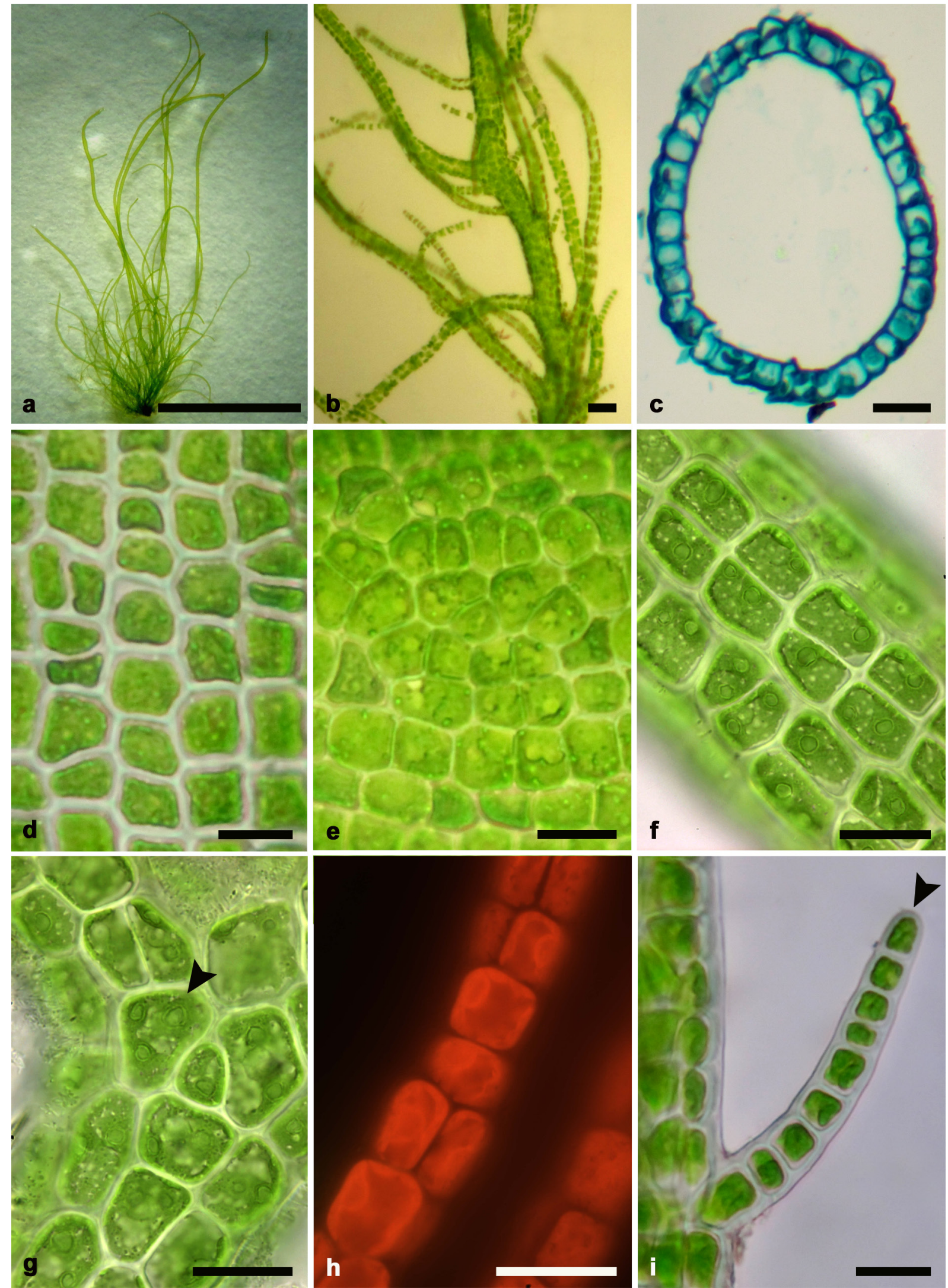

Fig. 2. Morphological characteristics for the population of U. flexuosa subsp. paradoxa: (a) overall habit showing the small-sized, light green filiform thallus; (b) intensive ramification of the thallus; (c) light green-stained transverse section from the midregion of broad thallus showing the tubular structure and the monostromatic layer; (d) close-up view on the quadrangular and polygonal vegetative cells well-ordered in long rows in the midregion of the thallus; (e) irregularly arranged vegetative cells in the central part of the thallus; (f) rectangular cells in a branch showing parietal chloroplasts covering the majority of the cell walls and with 1-2 pyrenoids; (g) a rounded-polygonal vegetative cell (arrowhead) with a parietal chloroplast and 3 pyrenoids; (h) autofluorescent chloroplasts; (i) a branchlet with a small rounded-conical apical cell (arrowhead). Scale bars $0.5 \mathrm{~cm}$ (a), $200 \mu \mathrm{m}$ (b), $20 \mu \mathrm{m}$ (c-i). 


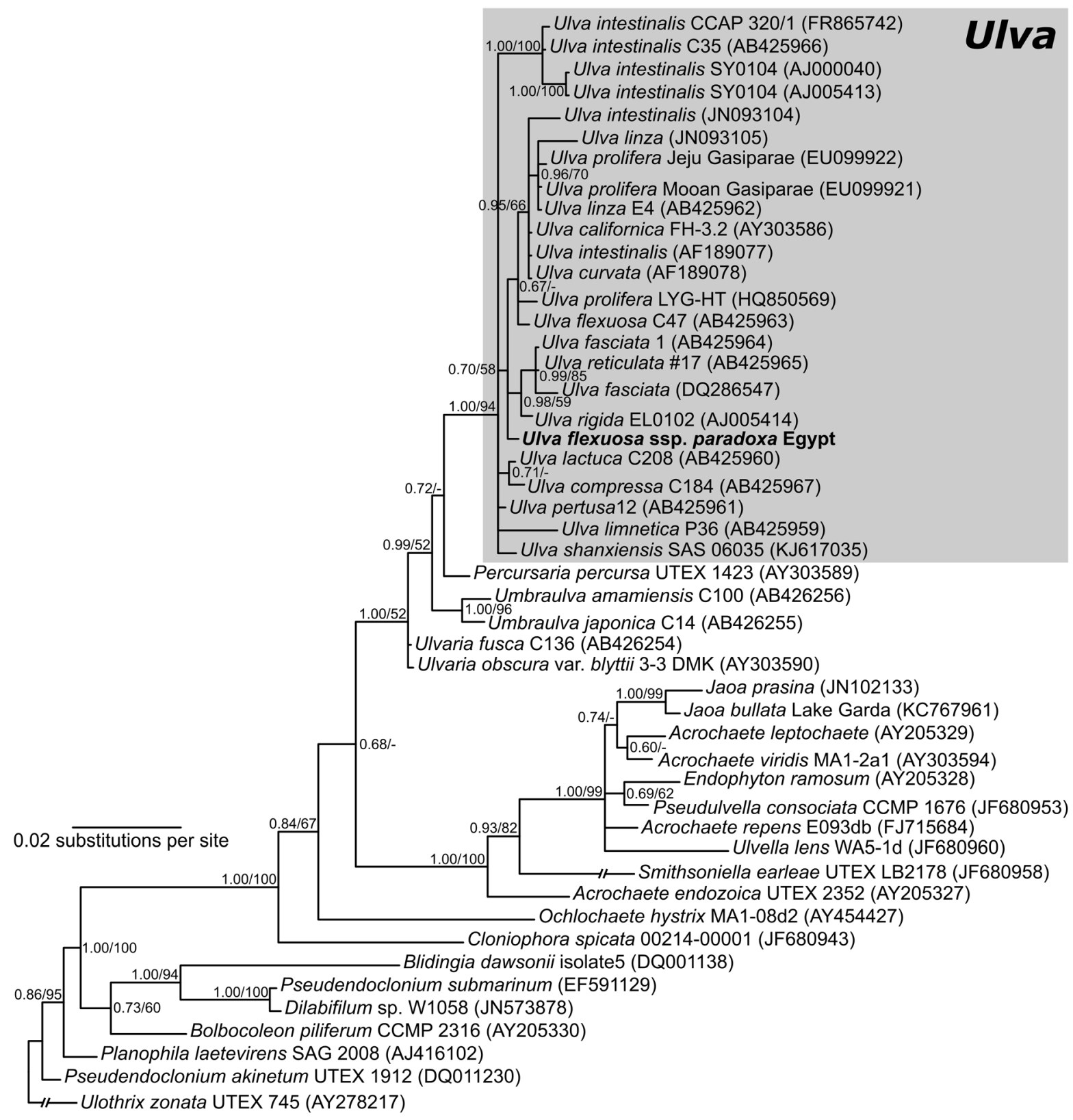

Fig. 3. Phylogenetic tree of Ulvophyceae inferred from the SSU rRNA gene data showing the position of U. flexuosa ssp. paradoxa (isolate from this study is printed in bold font). The monophyletic genus Ulva is shaded in grey. The tree was calculated using Bayesian Inference, branch supports $>50 \%$ are given at nodes in this shape: Bayesian Inference/Maximum Likelihood.

small different polarity of their head-groups.

All the lipid classes contain only $\mathrm{C} 16$ and $\mathrm{C} 18$ fatty acyl chains. MGDG 34:7 and MGDG 34:8, built on 16:4, 18:4 and 18:3 acyl chains, are the main MGDG lipid species $(\mathrm{ACL}=34.0)$ (Fig. 6a), whilst the most abundant DGDG lipid species $(\mathrm{ACL}=34.3)$ were found DGDG 36:2 and DGDG 34:2, built on 16:0, 18:0 and 18:2 acyl chains (check Table S2 for more details). DGTS molecular species ranges from 32 to 44 carbon atoms $(\mathrm{ACL}=35.7)$ but the main components are DGTS $34: 2$ and DGTS 34:3, built on 16:0, 16:1, 18:1 and 18:2 acyl chains, in addition to DGTS 34:4 which contains other polyunsaturated fatty acids (PUFAs) such as 16:2, 16:3, $16: 4$ or $18: 3$. Worth of note, the low abundance DGTS species with higher molecular weight (DGTS 42:10, DGTS 44:10 etc.) should contain the polyunsaturated 20:5 and 22:6 omega-3 fatty acyl chains; not detected in other lipid classes of this alga. Finally, among SQDG lipid species $(\mathrm{ACL}=33.9)$, SQDG 34:1, SQDG 34:2 and SQDG 34:3 sum up to more than $75 \%$ of the overall SQDG lipid distribution (Fig. 6b; Table S2).

\section{Discussion}

Most of the morphometric diagnostic features of the Siwa Ulva flexuosa subsp. paradoxa examined are in a 


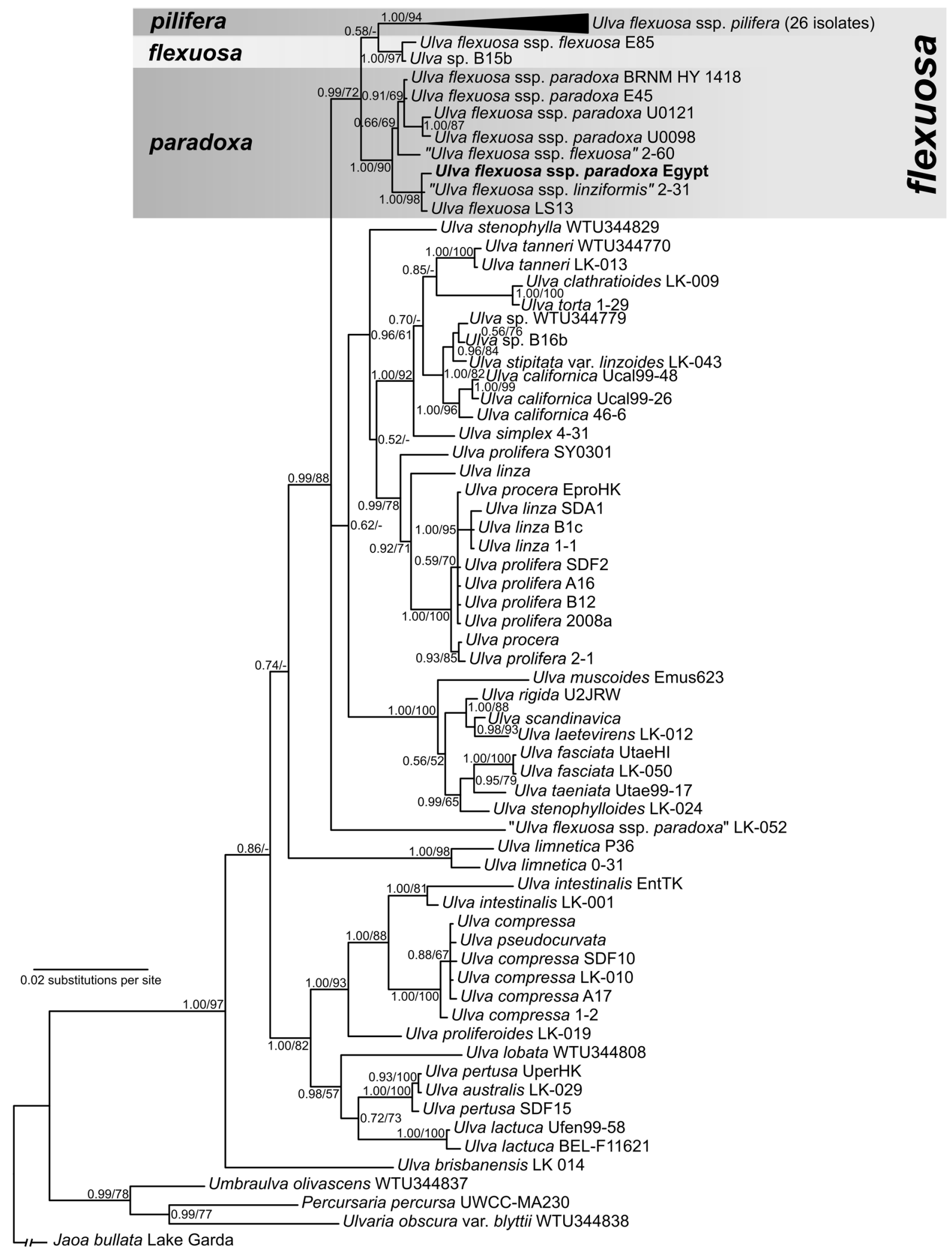

Fig. 4. Phylogenetic tree of Ulva inferred from the combined alignment of the nrDNA ITS region and the $r b c \mathrm{~L}$ gene (isolate from this study is printed in bold font). Ulva flexuosa forms one of the major infrageneric lineages of Ulva and is divided into three subclades corresponding to subspecies (shaded in grey). The tree was calculated using Bayesian Inference, branch supports $>50 \%$ are given at nodes in this shape: Bayesian Inference/Maximum Likelihood. 
good agreement with descriptions available in the relevant literature (e.g., BLIDING 1963; MAREŠ et al. 2011). However, the width of thalli was near the lower limit of the range usually reported for this taxon $(100-250 \mu \mathrm{m})$. In their recent contribution, RYBAK et al. (2014) reported samples of subsp. paradoxa with a comparable (although in average still larger) width of 50-400 $\mu \mathrm{m}$, suggesting that very narrow filiform thalli may be in fact relatively common in this taxon (see Table S1 for more details). This might be explained as environmentally-induced phenotypic plasticity common in the order Ulvales (Blomster et al. 1999; Messyasz \& RybaK 2011; RyBaK 2018). In general, precise morphological identification of the genus Ulva at the levels of species and subspecies is considered highly difficult and problematic, especially if based only on the traditional morphotaxonomic criteria.

The combined $r b c$ L-ITS phylogenetic analysis (Fig. 4) confirmed once again the monophyly of the $U$. flexuosa species complex (MAREŠ et al. 2011; RYBAK \& Czerwoniec 2015), which can be divided into the three known subspecies clades (flexuosa, paradoxa, pilifera). Recently, HiRAOKA et al. (2017) proposed a new criterion to separate biological species in Ulva, applying a threshold of $1.2 \%$ sequence distance in the ITS2 region that is correlated with the success of hybridization in cross-breeding experiments. According to this criterion the three $U$. flexuosa subspecies would clearly represent three separate species as their ITS2 distances were always $>3 \%$ (Table 2). In fact, the separate species U. paradoxa C. Agardh and U. pilifera (Kützing) Škaloud et Leliaert exist in literature, although these names are not used consistently. It was not the purpose of this study to decide which species concept should be applied, however the data suggest that $U$. flexuosa, $U$. paradoxa, and U. pilifera are distinct biological species.

The $r b c$ L-ITS phylogenetic tree placed the Siwa specimen with a good branch support value $(90 \%)$ together with other $U$. flexuosa subsp. paradoxa samples from Europe and Asia (Fig. 4). Intriguingly, the subspecies paradoxa specimen sequenced in this study was phylogenetically closely related to U. flexuosa subsp. linziformis specimens sequenced by OGAwA et al. (2013). In their study, they identified the Japanese Ulva specimens (with GenBank accession number AB830511) from a seashore locality as $U$. flexuosa subsp. linziformis on the basis of the scattered few branches near the base as well as the reproduction with only quadriflagellate zoids. This identification is taxonomically incompatible with other key diagnostic features of the subspecies linziformis in relevant literature such as the saccate thallus morphology and presence of 2-7 pyrenoids in each chloroplast (Bliding 1963; Koeman \& van Den Hoek 1984), and therefore can be considered invalid. BLIDING (1963) also showed that the chloroplasts in the subspecies linziformis are reticulate; not peripheral as documented by OGAwA et al. (2013). On the other hand the Japanese material clearly exhibits morphotaxonomic and ecological (high-salinity brackish sites) features corresponding to the subspecies paradoxa: a slender tubular thallus, abundant branching around the thallus base, uniseriate branches with a conical apical cell, cells rectangular to slightly rounded and arranged in long rows, and finally containing only 1-2 pyrenoids (OGAWA et al. 2013). The sequences of ITS2 regions were 100\% identical between the Egyptian and the Japanese isolates, which is way below the recently proposed threshold for separating biological species (HIRAOKA et al. 2017). We therefore suggest that the identification of the material from Japan should be corrected to be U. flexuosa subsp. paradoxa (syn. U. paradoxa). It should however be noted that two strains with a value lower than the $1.2 \%$ distance do not necessarily have to belong to the same species. Reproductive incompatibility has been previously found between some Ulva strains with identical ITS2 sequences (HIRAOKA et al. 2011). Hybridization experiments are thus required to provide conclusive evidence. Interestingly, the Japanese material, like our sample from Egypt, is characterized by very narrow thalli (about $100 \mu \mathrm{m}$, see also Table S1), which could therefore be a common trait in this sub-clade.

Another sequenced sample of $U$. flexuosa isolated from a massive green algal bloom in the Yellow Sea, China (ZHANG et al. 2011; accession number HM031156) was also closely allied to our specimen and the Japanese one in the $r b c \mathrm{~L}-\mathrm{ITS}$ phylogenetic tree (Fig. 4). Although morphology data is missing for the Chinese material, molecular data strongly suggest that it also belongs to $U$. flexuosa subsp. paradoxa. This finding extends the knowledge on the potential of this infraspecific taxon as a fouling species. Expansive behaviour and formation of blooms was previously reported in the subspecies pilifera in small freshwater reservoirs in Europe (KAŠTOVSKÝ et al. 2010; MAREŠ et al. 2011), and U. flexuosa without subspecies identification in a coastal lake of Lake

Table 2. The sequence variability in the taxonomically significant nrDNA ITS2 region and the $r b c$ Lene expressed as the range of pairwise p-distances between the subspecies of Ulva flexuosa. Internal divergence values within the subspecies clades are shaded grey.

\begin{tabular}{ccccccc}
\hline$\%$ & \multicolumn{2}{c}{ flexuosa } & \multicolumn{2}{c}{ paradoxa } & \multicolumn{2}{c}{ pilifera } \\
\hline & ITS2 & $\boldsymbol{r b c L}$ & ITS2 & $\boldsymbol{r b c L}$ & ITS2 & $\boldsymbol{r b c L}$ \\
flexuosa & 0.0 & 0.2 & & & & \\
paradoxa & $3.9-4.5$ & $0.5-1.0$ & $0.0-1.1$ & $0.2-1.0$ & & $0.0-1.1$ \\
pilifera & 6.4 & $1.1-1.8$ & $3.7-4.3$ & $1.6-2.1$ & 0.0 & \\
\hline
\end{tabular}



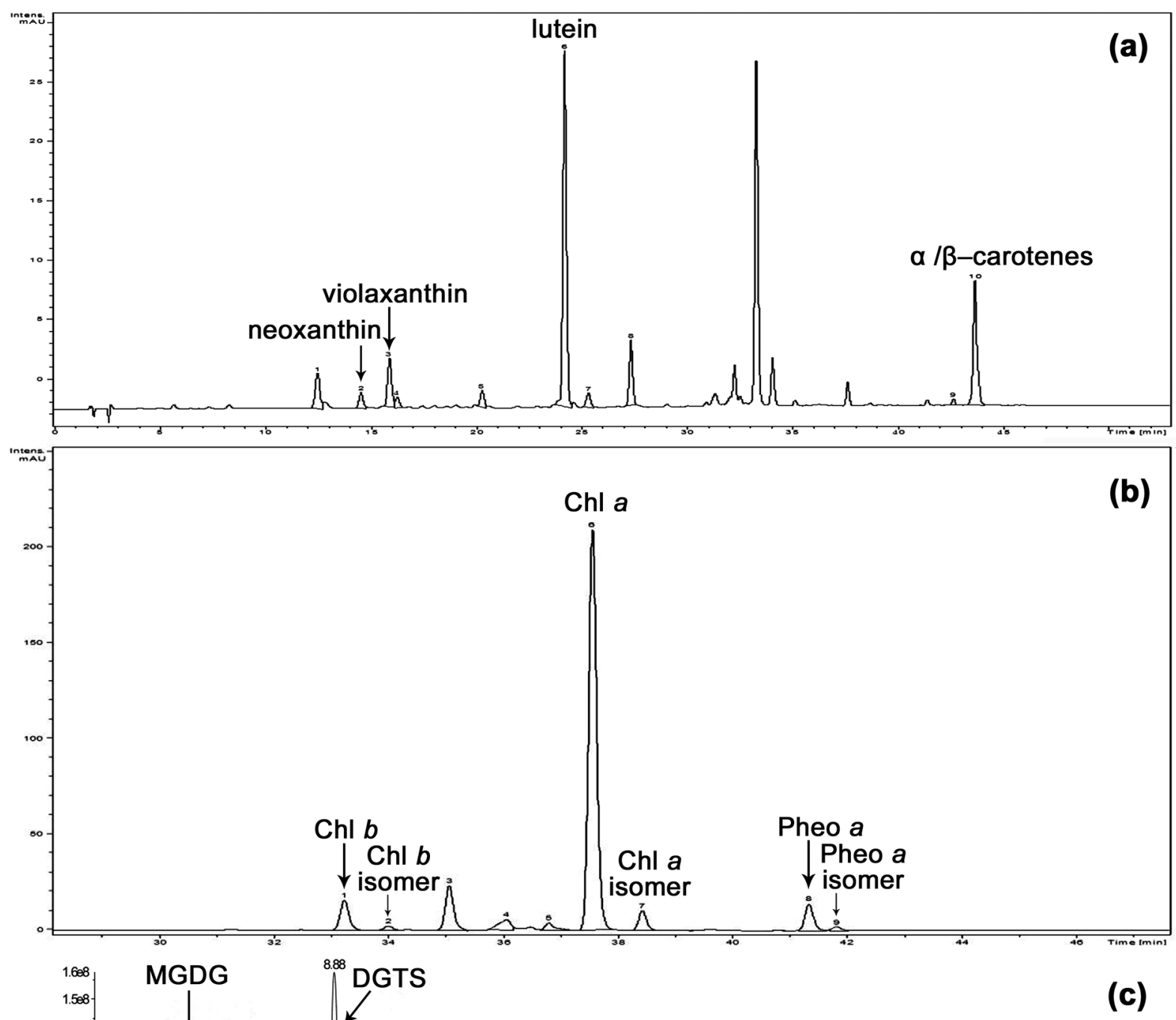
at $\lambda 470 \mathrm{~nm}$ (carotenoids); (b) RP8 chromatogram as detected by PDA at $\lambda 665 \mathrm{~nm}$ (chlorophylls); (c) HILIC chromatogram as detected by full scan ESI $(+)$ mass spectrometer (lipid classes). Intra-class lipid distribution was obtained in reversed-phase chromatographic conditions. 
Michigan (Lougheed \& Stevenson 2004). Our taxonomic analysis therefore strengthens the evidence for a common tendency to form algal blooms within the whole U. flexuosa complex (LIU et al. 2013; RYBAK \& GĄBKA 2017), which deserves further monitoring. This study, and many other references, confirm that the integrated approach, including morphology-and molecular-based taxonomy utilizing suitable gene markers, is nowadays an important prerequisite to unravel the taxonomic puzzle of members of the order Ulvales; especially in the relatively untouched habitats in Africa. Accordingly, LELIAERT \& DE CLERCK (2017) focused on the necessity of using multi-locus DNA data sets to precisely define more realistic species boundaries in cases where morphological/ecological divergence is lagging.

Springs with a distinct pool at the springhead and an outflowing streamlet are classified as limno-rheocrenes. They are frequent only in specific geographic areas (e.g., Finland; LeHosmaA et al. 2017), and in many cases this special morphology has been accentuated by human alterations such as digging of the pool and/or damming of the outlet. The spring studied belongs to this ecomorphological category, and U. flexuosa subsp. paradoxa was found only in the outlet channel, i.e. in the rheocrenic (flowing) part of the spring. From the ecological point of view, the Siwa U. flexuosa subsp. paradoxa population occurs in a high-mineral-concentration (VAN DER AA 2003), chloride sodium sulphate, low-nitrate (due to biological consumption?), oligo-mesotrophic (DoDDs et al. 1998) spring habitat (Table 1), in partial agreement with previous reports of the taxon in other parts of the world (RYBAK et al. 2014). Cyanobacterial taxa identified in Ain Abu Sherouf, such as Oscillatoria limosa and Phormidium tergestinum, suggest a relatively "polluted" (nutrient-rich) status (KOMÁREK \& ANAGNOSTIDIS 2005). The high concentration of sulphate in this Saharan spring ecosystem may also favor the proliferation of this fouling algal species. Accordingly, RYBAK et al. (2014) and RYBAK \& CZERWONIEC (2015) pointed out that the subspecies paradoxa mainly prefers extremely saline waters, and it can also tolerate high nitrate and

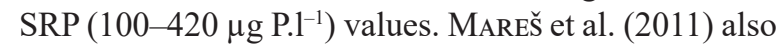
documented that members of the $U$. flexuosa complex usually proliferate in environments rich in dissolved ions; in particular chlorides and sulphates, and conductivities higher than those typical of freshwater habitats. Finally, the $U$. flexuosa subsp. paradoxa population studied is a good indicator for the environmental condition of the limno-rheocrenic mineral spring "Ain Abu Sherouf”, and the recent contribution of RYBAK \& GĄBKA (2017) suggests that the $U$. flexuosa blooms in inland waters may be controlled by reducing the sulphate input.

The pigment profile of $U$. flexuosa subsp. paradoxa does not present peculiar features. It meets expectations for an alga belonging to the Ulvophyceae, with lutein, neoxanthin, violaxanthin, and $\alpha / \beta$-carotene as the most abundant carotenoids, besides, among essential photosynthetic pigments, chlorophyll $a$ and chlorophyll- $b$
Table 3. Results of the membrane lipidomics analysis of the Siwa Ulva flexuosa subsp. paradoxa detailed per lipid class.

\begin{tabular}{lcccc}
\hline Items & \multicolumn{4}{c}{ Lipid classes } \\
& MGDG & DGDG & SQDG & DGTS \\
\hline species & 8 & 17 & 12 & 62 \\
UI & 6.14 & 2.73 & 2.02 & 4.21 \\
ACL & 34.0 & 34.29 & 33.88 & 35.73 \\
\hline Total number of lipid molecu- & & &
\end{tabular}

Total number of lipid molecular species

99

(MGDG) monogalactosyl diacylglycerols; (DGDG) digalactosyl diacylglycerols; (SQDG) sulfoquinovosyl diacylglycerols; (DGTS) diacylglyceryl $\mathrm{N}, \mathrm{N}, \mathrm{N}$-trimethylhomoserine; (UI) the unsaturation index of each lipid class; (ACL) average chain length for each lipid class.

(a)

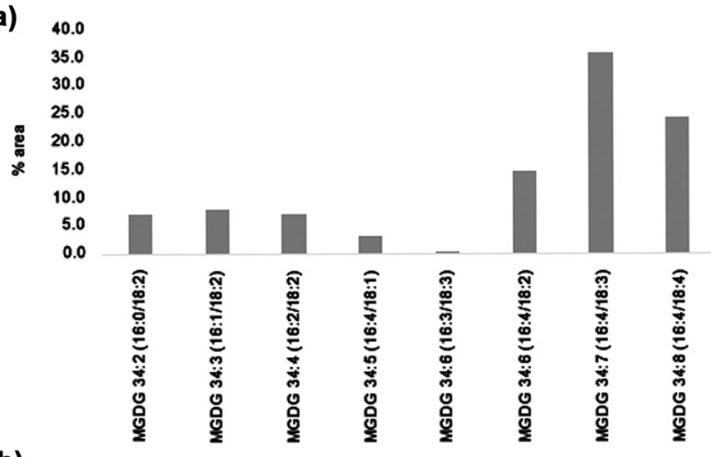

(b)

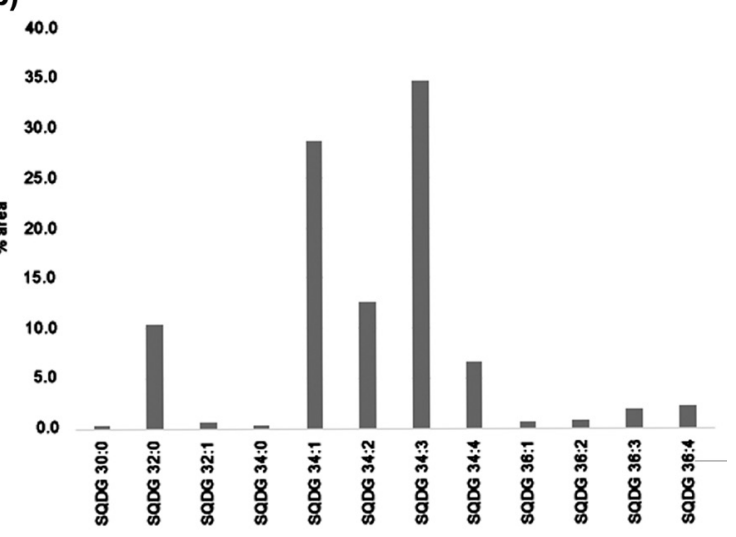

Fig. 6. Distribution of some lipid molecular species of $U$. flexuosa subsp. paradoxa specimens in this study: (a) monogalactosyl diacylglycerols (MGDG); (b) sulfoquinovosyl diacylglycerols (SQDG).

(TAKAICHI 2011). As opposed to a recent similar study (MAREŠ et al. 2014) of a related Ulvacean alga, Ulvella bullata (C.-C.Jao) H. Zhu et G. Liu, siphonaxanthin was not detected. It is however known that its presence is typically restricted to some species of Cladophorales. In general, it is well-known that carotenoid formation provides cell resistance to oxidative stresses produced by unfavorable environmental conditions including excess solar irradiation, UV, and salinity, therefore favoring survival in these harsh habitats (OREN et al. 1995; OrOSA et al. 2001; ABURAI et al. 2015). 
Some environmental characteristics, such as temperature and nutrient (specifically P) availability, are important abiotic drivers affecting lipid-class composition of algal cell membranes, and thus their fluidity and permeability, and $\mathrm{P}$ content (SABER et al. 2016; GonZALEZ-SiLVERA et al. 2017; HaYASHIDA et al. 2017). In this study, the inter-classes distribution of the membrane lipids was in line with our expectations revealing the presence of several lipid species in all the relevant classes MGDG, DGDG, SQDG, and DGTS. The latter has structural similarity with phosphatidyl-choline (PC) lipid class but does not contain any phosphate group in its head; typically, DGTS replace PC lipids in the outer cell membrane under P-limiting conditions (RIEKHOF et al. 2014). The extra-plastid membrane DGTS lipids might therefore be considered an adaptation to this spring habitat with relatively low phosphorus values.

The molar ratio [MGDG]/[DGDG] determined by quantitative MS was found to be 1.2, in fair agreement with the expected value in green algae as well as the UI distribution of the fatty acyl chains among the different lipid classes (MAAzOUZI et al. 2007). UI varied consistently among lipid classes with SQDG (2.0) and DGDG (2.7) bearing significantly more saturated acyl chains with respect to DGTS (4.2) and, above all, MGDG (6.1). The lower UI values of the plastidial DGDG and SQDG lipids appear to play a pivotal role in maintaining adequate membrane fluidity in this thermal habitat. In accordance with this observation, SABER et al. (2016) inversely documented a high unsaturation index (UI) and long acyl chains for the plastidial lipid class monogalactosyl diacylglycerols (MGDG) of the red alga Lemanea fluviatilis inhabiting a cold, glacial alpine habitat, as an adaptive strategy for maintaining adequate membrane fluidity and all metabolic processes. In addition, the presence of more saturated acyl chains in the DGDG and SQDG lipid classes could be another physiological adaptation of $U$. flexuosa subsp. paradoxa to this high conductivity habitat (T.D.S. $=5300 \mathrm{mg} . \mathrm{l}^{-1}$ ). Accordingly, GonZALEZ-SILVERA (2017) pointed out that the amount of saturated fatty acids in Chroothece richteriana (Rhodophyta) was directly and inversely related with the conductivity of the medium. Finally, the highest UI values in MGDG and lowest in SQDG of $U$. flexuosa subsp. paradoxa is a common finding in green algae (CRANWELL et al. 1990; ZHUKOvA \& AizDAICHER 1995).

The current polyphasic study of the green alga $U$. flexuosa subsp. paradoxa (syn. U. paradoxa) inhabiting a desert, thermal, high-mineral-concentration spring habitat in Africa is one of our recent in-depth investigations to unveil the cryptic and hidden algal and cyanobacterial diversity in Egypt, with the characterization of systematic positions and comparisons with related taxa worldwide. It also aims at contributing to a better understanding of algal ecophysiological adaptations to the harsh Saharan habitats.

\section{ACKNOWLEDGEMENTS}

Authors are thankful to Dr Jacopo Gabrieli (Institute for the Dynamics of Environmental Processes of the Italian Research Council \& Department of Environmental Sciences of the University of Venice) for making available the results of heavy metals and trace elements analyses.

\section{REFERENCES}

AbDulaziz, A.M. \& FAID, A.M. (2015): Evaluation of the groundwater resources potential of Siwa Oasis using three-dimensional multilayer groundwater flow model, Mersa Matruh Governorate, Egypt. - Arabian Journal of Geosciences 8: 659-675.

Abou El-Kheir, W.S. \& Mekkey, L. (1986): Studies on the algal floras inhabiting different water sources in Egypt. 2. Lakes and Springs. - Phytologia 61: 285-296.

Aburai, N.; Sumida, D. \& ABE, K. (2015): Effect of light level and salinity on the composition and accumulation of free and ester-type carotenoids in the aerial microalga Scenedesmus sp. (Chlorophyceae). - Algal Research 8: 30-36.

Aleem, A.A. (1993): The marine algae of Alexandria, Egypt. - 139 pp., Faculty of Science, Alexandria Uni., Egypt.

ANESI, A. \& Guella, G. (2015): A fast liquid chromatography-mass Spectrometry methodology for membrane lipid profiling through hydrophilic interaction liquid chromatography. - Journal of Chromatography A 1384: 44-52.

BAE, E.H. \& LEE, I.K. (2001): Umbraulva, A new genus based on Ulva japonica (Holmes) Papenfuss (Ulvaceae, Chlorophyta). - Algae 16: 217-231.

Bliding, C. (1963): A critical survey of European taxa in Ulvales. Part I: Capsosiphon, Percursaria, Blidingia, Enteromorpha. - Opera Botanica 8: 1-160.

Blomster, J.; Maggs, C.A. \& Stanhope, M.J. (1999): Extensive intraspecific morphological variation in Enteromorpha muscoides (Chlorophyta) revealed by molecular analysis. - Journal of Phycology 35: 575-586.

Bravakos, P.; Kotoulas, G.; Skaraki, K.; Pantazidou, A. \& ECONOMOU-AmilLI, A. (2016): A polyphasic taxonomic approach in isolated strains of cyanobacteria from thermal springs of Greece. - Molecular Phylogenetics and Evolution 98: 147-160.

Burland, T.G. (1999): DNASTAR's Lasergene Sequence Analysis Software. - Methods in Molecular Biology 132: 71-91.

CANTONATI, M.; FÜREDER, L.; GeRECKe, R.; JÜTTNER, I. \& Cox, E.J. (2012): Crenic habitats, hotspots for freshwater biodiversity conservation: toward an understanding of their ecology. - Freshwater Science 31: 463-480.

Cantonati, M.; Gerecke, R. \& Bertuzzi, E. (2006): Springs of the Alps-sensitive ecosystems to environmental change: From biodiversity assessments to long-term studies. - Hydrobiologia 562: 59-96.

Chapman, H.D. \& Pratt, P.F. (1978): Methods of analysis for soil, plants and water. - pp. 309, Division of Agricultural Sciences, University of California, Oakland CA.

Clesceri, L.S.; Greenberg, A.E. \& Eaton, A.D. (2000): Standard methods for the examination of water and wastewater, $20^{\text {th }}$ edition. -1325 pp., American Public Health Association, Washington D.C.

Cranwell, A.; Jaworski, G.H.M. \& Bickley, H.M. (1990): Hydrocarbons, sterols, esters and fatty acids in six 
freshwater chlorophytes. - Phytochemistry 29: 145-151.

Darriba, D.; TABoada, G.L.; Doallo, R. \& Posada, D. (2012): jModelTest 2: more models, new heuristics and parallel computing. - Nature Methods 9: 772.

Dodds, W.K.; Jones, J.R. \& WeLCH, E.B. (1998): Suggested classification of stream trophic state: distributions of temperate stream types by chlorophyll, total nitrogen, and phosphorus. - Water Research 32: 1455-1462.

Duan, W.; Guo, L.; Zhu, S.; Sun, D.; Zhu, S.; Chen, X.; Zhu, W.; Xu, T. \& Chen, C. (2012): Morphological and molecular characterization of free-floating and attached green macroalgae Ulva spp. in the Yellow Sea of China. - Journal of Applied Phycology 24: 97-108.

El ShoubaKy, G.A. (2005): Seasonal variations of seaweeds at El Arish coast of Mediterranean Sea (Egypt). - Egyptian Journal of Phycology 6: 39-55.

El Shoubaky, G.A. (2013): Comparison of the impacts of climate change and anthropogenic disturbances on the El Arish coast and seaweed vegetation after ten years in 2010, North Sinai, Egypt. - Oceanologia 55: 663-685.

EL ShoubaKy, G.A. (2015): On the annually recurrent of green macroalgal bloom phenomenon in Timsah Lake, Suez Canal, Egypt. - Journal of Biodiversity and Environmental Sciences 6: 300-309.

El-Sabbagh, A.; El-Hedeny, M. \& Al Farraj, S. (2017): Thalassinoides in the Middle Miocene succession at Siwa Oasis, northwestern Egypt. - Proceedings of the Geologists' Association 128: 222-233.

EL-SabBaGH, A.M. \& El Hedeny, M.M. (2016): A shell concentration of the Middle Miocene Crassostrea gryphoides (Schlotheim, 1813) from Siwa Oasis, Western Desert, Egypt. - Journal of African Earth Sciences 120: 1-11.

EL-ShoubaKy, G.A. \& HAMED, A.F. (2006): The characteristic algal mats and flora of El-Timsah Lake. - Catrina 1: 75-80.

FAKhry, E.M.; El Maghraby, D.M.; TAHA, H.M. \& Osman, M. (2007): Relationship evidences for some species belonging to family Ulvaceae. - Egyptian Journal of Phycology 8: 81-97.

Flaim, G.; Obertegger, U.; Anesi, A. \& Guella, G. (2014): Temperature-induced changes in lipid biomarkers and mycosporine-like amino acids in the psychrophilic dinoflagellate Peridinium aciculiferum. - Freshwater Biology 59: 985-997.

Fleming, T. (2016): Analysis of freshwater and marine Ulva flexuosa in Southern California. M.Sc. Thesis. - pp. 27, California State University, San Marcos.

Folch, J.; Lees, M. \& Sloane Stanley, G.H. (1957): A simple method for the isolation and purification of total lipids from animal tissues. - Journal of Biological Chemistry 226: 497-509.

Frassanito, R.; Cantonati, M.; Tardìo, M.; Mancini, I. \& GuELLA, G. (2005): On-line identification of secondary metabolites in freshwater microalgae and cyanobacteria by combined liquid chromatography-photodiode array detection-mass spectrometric techniques. - Journal of Chromatography A 1082: 33-42.

Glazier, D.S. (2009): Springs. - In: Likens, G.E. (ed.): Encyclopedia of Inland Waters, Vol. 1. - pp. 734-755, Academic Press Elsevier, Oxford.

Gonzalez-Silvera, D.; Pérez, S.; Korbee, N.; FigueroA, F.L.; ASENCIO, A.D.; ABOAL, M. \& LóPEZ-JiMÉNEZ, J.Á. (2017): Effects of global change factors on fatty acids and mycosporine-like amino acid production in Chroothece richteriana (Rhodophyta). - Journal of Phycology 53: 999-1009.

Guella, G.; Frassanito, R. \& Mancini, I. (2003): A new solution for an old problem: the regiochemical distribution of the acyl chains in galactolipids can be established by electrospray ionization tandem mass spectrometry. - Rapid Communications in Mass Spectrometry 17: 1982-1994.

Guindon, S. \& Gascuel, O. (2003): A simple, fast, and accurate algorithm to estimate large phylogenies by maximum likelihood. - Systematic Biology 52: 696-704.

HaLl, T.A. (1999). BioEdit: a user-friendly biological sequence alignment editor and analysis program for Windows 95/98/NT. - Nucleic Acids Symposium Series 41: 95-98.

Hayashida, G.; Schneider, C.; Espíndola, L.; Arias, D.; Riquelme, C.; WulfF-Zottele, C.; Díaz-Palma, P. \& Rivas, M. (2017): Characterization of a Chlorophyta microalga isolated from a microbial mat in Salar de Atacama (northern Chile) as a potential source of compounds for biotechnological applications. - Phycological Research 65: 202-211.

Hayden, H.S.; Blomster, J.; Maggs, C.A.; Silva, P.C.; Stanhope, M.J. \& WaAland, J.R. (2003): Linnaeus was right all along: Ulva and Enteromorpha are not distinct genera. - European Journal of Phycology 38 : 277-294.

Hayden, H.S. \& WaAland, J.R. (2002): Phylogenetic systematics of the Ulvaceae (Ulvales, Ulvophyceae) using chloroplast and nuclear sequences. - Journal of Phycology 38: 1200-1212.

Hiraoka, M.; Ichihara, K.; Zhu, W.; Ma, J. \& Shimada, S. (2011): Culture and hybridization experiments on an Ulva clade including the Qingdao strain blooming in the Yellow Sea. - PLoS ONE 6: e19371.

Hiraoka, M.; Ichihara, K.; Zhu, W.; Shimada, S.; OKa, N.; Cui, J.; Tsubaki, S. \& He, P. (2017): Examination of species delimitation of ambiguous DNA-based Ulva (Ulvophyceae, Chlorophyta) clades by culturing and hybridization. -Phycologia 56: 517-532.

Hofmann, L.C.; Nettleton, J.C.; Neefus, C.D. \& Mathieson, A.C. (2010): Cryptic diversity of Ulva (Ulvales, Chlorophyta) in the Great Bay estuarine system (Atlantic USA): introduced and indigenous distromatic species. - European Journal of Phycology 45: 230-239.

IChiHARA, K.; Arai, S.; UChimURA, M.; FAY, E.J.; EbATA, H.; Hiraoka, M. \& Shimada, S. (2009): New species of freshwater Ulva, Ulva limnetica (Ulvales, Ulvophyceae) from the Ryukyu Islands, Japan. - Phycological Research 57: 94-103.

ISMAIL, M.M. \& MoHAMED, S.E. (2017): Differentiation between some Ulva spp. by morphological, genetic and biochemical analyses. - Vavilov Journal of Genetics and Breeding 21: 360-367.

John, D.M. (2011): Order Ulvales. - In: JoHN, D.M.; WhitTon, B.A. \& BRooK, A.J. (eds): The freshwater algal flora of the British Isles: An identification guide to freshwater and terrestrial algae. - pp. 575-576, Cambridge University Press, Cambridge.

KaštovskÝ, J.; HaUer, T.; Mareš, J.; KRAutová, M.; BeŠTa, T.; KomÁrek, J.; Desortová, B.; HetešA, J.; HindÁková, A.; Houk, V.; JaneČeK, E.; Kopp, R.; Marvan, P.; PumanN, P.; SKÁCElOvá, O. \& ZAPOMĚLová, E. (2010): A review of the alien and expansive species of freshwater cyanobacteria and algae in the Czech Republic. - Biological Invasions 12: 3599-3625.

KATOH, K. \& StAndley, D.M. (2013): MAFFT multiple 
sequence alignment software version 7: improvements in performance and usability. - Molecular Biology and Evolution 30: 772-780.

KaZI, M.A.; KaVALE, M.G. \& Singh, V.V. (2016): Morphological and molecular characterization of Ulva chaugulii sp. nov., U. lactuca and U. ohnoi (Ulvophyceae, Chlorophyta) from India. - Phycologia 55: $45-54$.

KeEsing, J.K.; LiU, D.; ShI, Y. \& Wang, Y. (2016): Abiotic factors influencing biomass accumulation of green tide causing Ulva spp. on Pyropia culture rafts in the Yellow Sea, China. - Marine Pollution Bulletin 105: 88-97.

Koeman, R.P.T. \& van DEN Hoek, C. (1984): The taxonomy of Enteromorpha Link, 1820, (Chlorophyceae) in the Netherlands. III. The sections Flexuosae and Clathratae and an addition to the section Proliferae. - Cryptogamie, Algologie 5: 21-61.

KomÁrek, J. \& ANAGnostidis, K. (2005): Cyanoprokaryota 2. Oscillatoriales. - In: BÜDEL, B.; GäRTNER, G.; KrienitZ, L. \& SCHAGERL, M. (eds): Süßwasserflora von Mitteleuropa, Band 19/2. - 760 pp., Elsevier $\mathrm{GmbH}$, München.

Kraft, L.G.K.; KRAFT, G.T. \& WaLLER, R.F. (2010): Investigation into southern Australian Ulva (Ulvophyceae, Chlorophyta) taxonomy and molecular phylogeny indicate both cosmopolitanism and endemic cryptic species. - Journal of Phycology 46: 1257-1277.

LeE, S.H.; KANG, P.J. \& NAM, K.W. (2014): New record of two marine ulvalean species (Chlorophyta) in Korea. - Journal of Ecology and Environment 37: 379-385.

LehosmaA, K.; JyvëSJärVI, J.; VirTANEN, R.; Rossi, P.M.; Rados, D.; Chuzhekova, T.; MarkKola, A.; Ilmonen, J. \& Muotka, T. (2017): Does habitat restoration enhance spring biodiversity and ecosystem functions? - Hydrobiologia 793: 161-173.

Leliaert, F. \& De Clerck, O. (2017): Refining species boundaries in algae. - Journal of Phycology 53: 12-16.

Liu, F.; PAnG, S.J.; Xu, N.; Shan, T.F.; Sun, S.; Hu, X. \& Yang, J.Q. (2010): Ulva diversity in the Yellow Sea during the large-scale green algal blooms in 2008-2009. Phycological Research 58: 270-279.

LiU, F.; PANG, S. \& ZHAO, X. (2013): Molecular phylogenetic analyses of Ulva (Chlorophyta, Ulvophyceae) mats in the Xiangshan Bay of China using high-resolution DNA markers. - Journal of Applied Phycology 25: 1287-1295.

Lougheed, V.L. \& Stevenson, R.J. (2004): Exotic marine macroalga (Enteromorpha flexuosa) reaches bloom proportions in a coastal lake of Lake Michigan. - Journal of Great Lakes Research 30: 538-544.

Maazouzi, C.; Masson, G.; Izquierdo, M.S. \& Pihan, J.-C. (2007): Fatty acid composition of the amphipod Dikerogammarus villosus: feeding strategies and trophic links. - Comparative Biochemistry and Physiology Part A: Molecular \& Integrative Physiology 147: 868-875.

Malta, E.J.; VerschuUre, J.M. \& Nienhuis, P.H. (2002): Regulation of spatial and seasonal variation of macroalgal biomass in a brackish, eutrophic lake. - Helgoland Marine Research 56: 211-220.

Mareš, J.; Cantonati, M.; Guella, G. \& Spitale, D. (2014): The benthic chlorophyte genus Jaoa (Ulvales), a putative China endemic, in Lake Garda, Italy: Ecology, taxonomy, and molecular analyses. - Freshwater Science 33: 593-605.

Mareš, J.; Leskinen, E.; Sitkowska, M.; Skácelová, O. \& Blomster, J. (2011): True identity of the European freshwater Ulva (Chlorophyta, Ulvophyceae) revealed by a combined molecular and morphological approach. - Journal of Phycology 47: 1177-1192.

Melton III, J.T.; Collado-Vides, L. \& LopeZ-Bautista, J.M. (2016): Molecular identification and nutrient analysis of the green tide species Ulva ohnoi M. Hiraoka \& S. Shimada, 2004 (Ulvophyceae, Chlorophyta), a new report and likely nonnative species in the Gulf of Mexico and Atlantic Florida, USA. - Aquatic Invasions 11: $225-237$.

Messyasz, B. \& RybaK, A. (2009): The distribution of green algae species from the Ulva genera (syn. Enteromorpha; Chlorophyta) in Polish inland waters. - Oceanological and Hydrobiological Studies 38: 121-138.

Messyasz, B. \& RyBAK, A. (2011): Abiotic factors affecting the development of Ulva sp. (Ulvophyceae; Chlorophyta) in freshwater ecosystems. - Aquatic Ecology 45: 75-87.

Miller, M.A.; Pfeiffer, W. \& Schwartz, T. (2012): The CIPRES science gateway: enabling high-impact science for phylogenetics researchers with limited resources. - In: Proceedings of the $1^{\text {st }}$ Conference of the Extreme Science and Engineering Discovery Environment: Bridging from the extreme to the campus and beyond. - pp. 1-8, ACM, Chicago, Illinois.

Nowicka-KraWczyK, P. \& Żelazna-WieczoreK, J. (2016): Dynamics in cyanobacterial communities from a relatively stable environment in an urbanised area (ambient springs in Central Poland). - Science of the Total Environment 579: 420-429.

O‘Kelly, C.J.; Wysor, B. \& Bellows, W.K. (2004): Gene sequence diversity and the phylogenetic position of algae assigned to the genera Phaeophila and Ochlochaete (Ulvophyceae, Chlorophyta). - Journal of Phycology 40: 789-799.

Ogawa, T.; OHKI, K. \& KamiYa, M. (2013): Differences of spatial distribution and seasonal succession among Ulva species (Ulvophyceae) across salinity gradients. - Phycologia 52: 637-651.

Oren, A.; KüHL, M. \& Karsten, U. (1995): An evaporitic microbial mat within a gypsum crust, zonation of phototrophs, photopigments, and light penetration. Marine Ecology Progress Series 128: 151-159.

Orosa, M.; Valero, J.F.; Herrero, C. \& Abalde, J. (2001): Comparison of the accumulation of astaxanthin in Haematococcus pluvialis and other green microalgae under N-starvation and high light conditions. Biotechnology Letters 23: 1079-1085.

Phillips, J.A.; Lawton, R.J.; Denys, R.; Paul, N.A. \& Carl, C. (2016): Ulva sapora sp. nov., an abundant tubular species of Ulva (Ulvales) from the tropical Pacific Ocean. - Phycologia 55: 55-64.

Powell, O; Silcock, J. \& Fensham, R.J. (2015): Oases to oblivion: the rapid demise of springs in the South-Eastern Great Artesian Basin of Australia. - Groundwater 53: $171-178$

Powell, O. \& Fensham, R. (2016): The history and fate of the Nubian Sandstone Aquifer springs in the oasis depressions of the Western Desert, Egypt. - Hydrogeology Journal 24: 395-406.

Reiss, M. \& Chifflard, P. (2017): An opinion on spring habitats within the earth's critical zone in headwater regions. - Water 9: 645. doi:10.3390/w9090645

Riekhof, W.R.; NAiK, S.; Bertrand, H.; Benning, C. \& Voelker, D.R. (2014): Phosphate starvation in fungi induces the replacement of phosphatidylcholine with the 
phosphorus-free betaine lipid diacylglyceryl $-N, N, N-$ trimethylhomoserine. - Eukaryotic Cell 13: 749-757.

Ronquist, F.; Teslenko, M.; van Der Mark, P.; Ayres, D.L.; Darling, A.; Hohna, S.; Larget, B.; LiU, L.; SuCHARD, M.A. \& HuELSENBECK, J.P. (2012): MrBayes 3.2: efficient Bayesian phylogenetic inference and model choice across a large model space. - Systematic Biology 61: 539-542.

RYBAK, A.S. \& GĄBKA, M. (2017): The influence of abiotic factors on the bloom-forming alga Ulva flexuosa (Ulvaceae, Chlorophyta): possibilities for the control of the green tides in freshwater ecosystems. - Journal of Applied Phycology. https://doi.org/10.1007/s10811-017-1301-5

Rybak, A.; Czerwoniec, A.; GąBKa, M. \& Messyasz, B. (2014): Ulva flexuosa (Ulvaceae, Chlorophyta) inhabiting inland aquatic ecosystems: molecular, morphological and ecological discrimination of subspecies. - European Journal of Phycology 49: 471-485.

RYBAK, A.S. (2015): Revision of herbarium specimens of freshwater Enteromorpha-like Ulva (Ulvaceae, Chlorophyta) collected from Central Europe during the years 1849-1959. - Phytotaxa 218: 1-29.

Rybak, A.S. (2016): Freshwater population of Ulva flexuosa (Ulvaceae, Chlorophyta) as a food source for great pond snail: Lymnaea stagnalis (Mollusca, Lymnaeidae). Phycological Research 64: 207-211.

Rybak, A.S. (2018): Species of Ulva (Ulvophyceae, Chlorophyta) as indicators of salinity. - Ecological Indicators 85: 253-261.

RyBAK, A.S. \& CZERWONIEC, A. (2015): Differentiation of inland Ulva flexuosa Wulfen (Ulvaceae, Chlorophyta) from Western Poland. - Oceanological and Hydrobiological Studies 44: 393-409.

Saber, A.A.; Cantonati, M.; Vis, M.L.; Anesi, A. \& Guella, G. (2016): Multifaceted characterization of a Lemanea fluviatilis population (Batrachospermales, Rhodophyta) from a glacial stream in the south-eastern Alps. - Fottea 16: 234-243.

SABER, A.A.; ICHIHARA, K. \& CANTONATI, M. (2017): Molecular phylogeny and detailed morphological analysis of two freshwater Rhizoclonium strains from contrasting spring types in Egypt and Italy. - Plant Biosystems 151(5): 800-812.

ShaAban, A.S. (1985): The algal flora of Egyptian oases. II. On the algae of Siwa oasis. - Proceedings of Egyptian Botanical Society 4: 1-10.

ShaAban, A.S.; Mansour, H.A. \& Saber, A.A. (2012): Phytoplankton in relation to some physico-chemical characteristics of water in Rosetta Branch of River Nile, Egypt. - Egyptian Journal of Botany 52: 483-497.

ShanAB, S.M.M. (2006): Algal flora of Ain Helwan. I. Algae of the warm spring. - Egyptian Journal of Phycology 7: 209-231.

Shimada, S.; Hiraoka, M.; Nabata, S.; Iima, M. \& Masuda, M. (2003): Molecular phylogenetic analyses of the Japanese Ulva and Enteromorpha (Ulvales, Ulvophyceae), with special reference to the free-floating Ulva. - Phycological Research 51: 99-108.

Shimada, S.; Yokoyama, N.; Arai, S. \& Hiraoka, M. (2008): Phylogeography of the genus Ulva (Ulvophyceae, Chlorophyta), with special reference to the Japanese freshwater and brackish taxa. - Journal of Applied
Phycology 20: 979-989.

StAMATAKIs, A. (2014): RAxML version 8: A tool for phylogenetic analysis and post-analysis of large phylogenies. - Bioinformatics 30: 1312-1313.

TAKAICHI, S. (2011): Carotenoids in algae: distributions, biosyntheses and functions. - Marine Drugs 9: 1101-1118.

TAlavera, G. \& CASTresana, J. (2007): Improvement of phylogenies after removing divergent and ambiguously aligned blocks from protein sequence alignments. Systematic Biology 56: 564-577.

VAN DER AA, M. (2003): Classification of mineral water types and comparison with drinking water standards. Environmental Geology 44: 554-563.

Voss, C.I. \& Soliman, S.M. (2014): The transboundary nonrenewable Nubian Aquifer System of Chad, Egypt, Libya and Sudan: classical groundwater questions and parsimonious hydrogeologic analysis and modeling. - Hydrogeology Journal 22: 441-468.

WynNe, M.J. (2017): A checklist of benthic marine algae of the tropical and subtropical western Atlantic: fourth revision. - Nova Hedwigia Beihefte 145: 1-202.

Yilmaz, M.; Phlips, E.J. \& Tillett, D. (2009): Improved methods for the isolation of cyanobacterial dna from environmental samples. - Journal of Phycology 45: $517-521$.

Yoshida, G.; Uchimura, M. \& Hiraoka, M. (2015): Persistent occurrence of floating Ulva green tide in Hiroshima Bay, Japan: seasonal succession and growth patterns of Ulva pertusa and Ulva spp. (Chlorophyta, Ulvales). - Hydrobiologia 758: 223-233.

Zhang, X.; Xu, D.; MaO, Y.; Li, Y.; Xue, S.; Zou, J.; Lian, W.; Liang, C.; ZhuANG, Z.; WanG, Q. \& YeA, N. (2011): Settlement of vegetative fragments of Ulva prolifera confirmed as an important seed source for succession of a large-scale green tide bloom. - Limnology and Oceanography 56: 233-242.

Zhukova, N.V. \& Aizdaicher, N.A. (1995): Fatty acid composition of 15 species of marine microalgae. Phytochemistry 39: 351-356.

Supplementary material

the following supplementary material is available for this article:

Table S1. Morphometrical and ecological comparative study between $U$. flexuosa subsp. paradoxa specimens in this study and other relevant literature.

Table S2. Details of lipidomics and pigments of $U$. flexuosa subsp. paradoxa specimens in this study.

Fig. S1. Additional morphotaxonomic features of the Siwa $U$. flexuosa subsp. paradoxa

This material is available as part of the online article (http:// fottea.czechphycology.cz/contents)

(C) Czech Phycological Society (2018)

Received February 19, 2018

Accepted May 23, 2018 